Citation:

Vinyals-Mirabent, S. (2019). European urban destinations' attractors at the frontier between competitiveness and a unique destination image. A benchmark study of communication practices. Journal of Destination Marketing \& Management, 12, 37-45.

Publisher: Journal of Destination Marketing \& Management (Elsevier) https://www.sciencedirect.com/science/article/pii/S2212571X18303500

\title{
EUROPEAN URBAN DESTINATIONS' ATTRACTORS AT THE FRONTIER BETWEEN COMPETITIVENESS AND A UNIQUE DESTINATION IMAGE. A BENCHMARK STUDY OF COMMUNICATION PRACTICES
}

\author{
Sara Vinyals-Mirabent* \\ Universitat Pompeu Fabra, Roc Boronat, 138, 08018, Barcelona, Spain
}

\begin{abstract}
:
The attractors of a destination are key elements of its appeal and play a vital role in the destination's success. Attractors, such as architecture or culture, have been identified as essential features of the destination's competitiveness and as distinguishing features useful for differentiating the destination's image from that of competitors. However, the limit between these two attractor roles is not yet definite. This investigation analyzes the function of different attractors in communication practices within the niche of European urban destinations. The study uses content analysis to identify the similarities and differences among the official communication of the twelve most popular urban destinations in Europe. The results point to tourism products and packages, cultural attractions, and gastronomy as critical elements for competing in this specific market. It further highlights that attractors such as history, accommodation, and leisure attractions act as the main sources for differentiation among the European cities.
\end{abstract}

Keywords: Destination branding; Destination attractors; Online communication; Projected brand image; Competitiveness; Destination image; Official websites 


\section{INTRODUCTION}

Destinations project their most striking signs to attract tourists and position themselves in the world. In particular, European destinations possess a singular high historical value, becoming a cluster of attractive cultural destinations (Therkelsen \& Gram, 2010). Characteristics such as architecture, heritage or culture, among others, make European cities unique and highly appealing as tourist destinations. Europe is presently the strongest region in tourism and travel competitiveness, entailing highly attractive countries, cities, towns, areas, etc, long experienced in the tourism industry (Schwab, Martin, Samans, Moavenzadeh, \& Dreniek-Hanouz, 2017).

However, the time when a single building or heritage attraction could drive tourists to choose a specific destination has long gone. Tourism has shifted towards the consumption of holistic experiences, far from the traditional sun and sand one (de San Eugenio Vela, 2011; Sack, 1992). Tourists seek overall experiences compounded by different characteristics of the destination. Among these characteristics, components such as gastronomy, infrastructure, accessibility of the destination, shopping possibilities, etc broaden the range of attractors contributing to the overall destination experience. Altogether, these are crucial characteristics of destinations deeply influencing their success (Wong \& Teoh, 2015). Consequently, the study of destinations' attractors has received great attention in past and recent research.

The multiplicity of attractors any destination brand encompasses makes the process of branding destinations a challenge (Pike, 2005). While a universal set of attractions useful for comparing competing destinations should be delimited, previous research notes the risk of using generalized sets of attractors since each destination and market segment has its particular characteristics (Enright \& Newton, 2005). As Mazanec and Strasser (2007) note, too-generic or reduced lists of attributes might mislead past and future research analyzing destinations' image. Thus, further comprehension of specific market segments' characteristics is needed to identify those traits that could be comparable within the segment and those that contribute to a greater extent to the uniqueness of the place. While studies from competitiveness theory continue to strive to identify those common attractors useful for comparing different destinations' competitiveness in the market (Crouch, 2011), destination brand image theory aims to identify those attractors unique to particular destinations (Qu, Kim, \& Im, 2011).

Furthermore, practitioners find the promotion of these attractors a challenge. To foster competitiveness and position the destination on the market, destination managers first need to compete online. Today's communication and marketing practices are the channels for exalting both the most relevant and the most differentiating characteristics of the territory (Nogue \& Albet, 2007). The online discourse of the destinations should be the reflection of the destination strategy (Fernández-Cavia, Marchiori, Haven-Tang, \& Cantoni, 2017; Luna-Nevarez \& Hyman, 2012). In their communications, destination managers simultaneously project the competence and uniqueness of the destination. After all, tourists' experiences should live up to the promise established in the managers' communications to be satisfactory (Oliveira, 2013). Thus, a better understanding of the role of the attractors in communication practices would contribute both to future research on a destination's competitiveness and brand image and to destination managers who 
endeavor to project competitiveness and build a unique destination image at the same time (Andrades-Caldito, Sánchez-Rivero, \& Pulido-Fernández, 2013).

This research is framed at the boundary between the relevance of certain attractors to project competitiveness and the role some of them have to represent the destination in a unique and distinguishing manner. Specifically, the aim of this research is twofold. On the one hand, it aims to identify the most dominant attractors of the destination's communication common to European urban destinations. On the other hand, this study aims to determine which attractors are the more differentiating features of specific destinations. It is a benchmark study of the most popular destinations in the European urban tourism context addressing previous research limitations, such as the need for developing studies narrowed to homogeneous destination sets (Mendola \& Volo, 2017). Additionally, it aims to establish the role of the attractors in online communication practices to contribute to cities' branding efforts. Studying the urban destinations market segment is particularly relevant due to the impact of cities' economic development in the country and their investment in branding and competitiveness (Anholt, 2004; Kavaratzis \& Ashworth, 2010).

\section{DESTINATIONS' ATTRACTORS}

Also referred to as attractions, attributes, resources, etc, previous literature identified a considerable diversity of items compounding the set of characteristics of the destination's offer (Enright \& Newton, 2005; Hong-bumm, 1998). In particular, investigations about the destination's competitiveness and brand image have intensively explored the influence of these elements on tourists' behaviors, loyalty, intent to recommend, etc (Wong \& Teoh, 2015; Zhang, Fu, Cai, \& Lu, 2014). However, the focus of both areas of study diverges. Whereas the destination image aims to identify the contribution of the attractors to the uniqueness of the destination (Qu et al., 2011), competitiveness seeks to delimit a set of universal attractors determining whether destinations are sufficiently competitive in the market and enable comparative studies across time and cases (Mendola \& Volo, 2017).

This complexity is a challenge for destination brand managers, who strive to project all these features on their official communications as a reflection of their destination strategies and positioning (Oliveira, 2013). Thus, even though a detailed discussion about destination image and competitiveness falls outside the scope of this paper, this study needs to highlight the connections between competitiveness studies and the destination image construct. For instance, elements of the destination's physiography, culture, accommodation, or transportation are those elements considered simultaneously in the competitiveness literature and in the destination image construct (Andrades-Caldito et al., 2013).

\subsection{DESTINATION COMPETITIVENESS}

The competitiveness of a destination refers to the brand's capability of successfully occupying a market niche in the long term. In Hassan's (2000, p. 239) words, it is the potential of 'creating and integrating value-added products to sustain resources while maintaining market position relative to other competitors.' In its origin, the study of competitiveness was restricted to the analysis of price and its potential to influence 
demand (Andrades-Caldito et al., 2013). Decades later, the study of competitiveness has shifted towards the definition of composite indicators to capture the multifaceted reality of destinations (Mendola \& Volo, 2017). Presently, a large body of research is dedicated to delimit the 'complex, latent and holistic nature of tourism destination competitiveness' (Mendola \& Volo, 2017, p.542).

Specifically, according to Crouch and Ritchie (1999; Ritchie \& Crouch, 2003), five major components contribute to destination competitiveness: resources and attractors; supporting factors and resources; destination management; qualifying determinants; and destination policy, planning, and development. Of all the items analyzed, the authors highlight resources and attractions as the fundamental elements of a destination's appeal and the primary reason for a tourist's choice (Crouch \& Ritchie, 1999). Years later, Crouch (2011) again confirmed the relevance of resources and attractiveness as the cornerstone of destination competitiveness. Similarly, the Travel and Tourism Competitiveness Index, one of the most influential competitiveness reports, highlights natural and cultural resources as 'the principal reason to travel' (Schwab et al., 2017, p.8).

Nevertheless, recent studies warned about the limitations of most of the competitive indicators for capturing each destination's specificities (Croes, 2011). According to Mazanec et al. (2007), objectively identifying the indicators for assessing attractiveness is a challenge, ultimately evaluated by variable supply-side descriptors, which hinders comparability across cases. Hence, the need to define variables sufficiently broad as to enable comparative studies might have contributed to the loss of relevant information about the particular competitive context (Mendola \& Volo, 2017).

Both the use of nonrelevant indicators and the unawareness of traits possibly relevant in particular segments have misled previous research (Mazanec \& Strasser, 2007). Several attempts to describe destination attractiveness have used indicators weakly related to tourism or have ignored the geographical and market-related characteristics of different destinations (Ayikoru, 2015; Mendola \& Volo, 2017). Thus, knowledge about the characteristics of specific markets contributing to the definition of a tailored set of indicators (i.e. attractors) would be of great utility for future studies on destination competitiveness (Mazanec \& Ring, 2011).

\subsection{DESTINATION BRAND IMAGE}

Destination brand image can be defined as the consumer's perception of a brand, represented by a network of associations linked to the brand name in the consumer's memory (Keller, 1993). Destinations aim to position positive images in potential or actual tourists' minds through the sum of characteristics describing that which is and what that which can be found at the destination (Baloglu \& McCleary, 1999; Pike, 2012; Qu, Kim, \& Im, 2011; Souiden, Ladhari, \& Chiadmi, 2017). Even though a universal classification of destination image associations does not yet exist (Pike \& Page, 2014), destination image comprises both symbolic and functional associations (Daye, 2010; Hosany, Ekinci, \& Uysal, 2006; Qu et al., 2011).

In particular, the functional dimension of brand image has gathered great attention among academics (Pike \& Page, 2014). These associations are frequently described as encompassing all the attributes perceived as utilitarian, rational, tangible, physical, or 
product related (Kapferer, 2012; Keller \& Lehmann, 2006; S. Kim \& Lehto, 2013). As Keller (1993) defined, a main source of image associations is the product characteristics and other features related to the product. Hence, the various products and attractors of the destination become functional associations contributing to the formation of the overall impression of the destination in tourists' minds (MacKay \& Fesenmaier, 1997; MartínSantana, Beerli-Palacio, \& Nazzareno, 2017). According to Enright and Newton (2005, p.341), 'the core resources and attractions constitute the primary elements of destination appeal and include physiography, culture and history, market ties, activities, special events, and the tourism superstructure,' and all of them must participate in the brand image construction.

However, different from destination competitiveness theory, brand image theory deems the destination's attractors to be key features making the brand unique and distinguishing it in consumers' minds towards the desired positioning (Echtner \& Ritchie, 1993; Qu et al., 2011; Stepchenkova \& Morrison, 2008). While competitiveness studies aim to delimit broad indicators useful across cases, destination image aims to promote them as a unique DNA string.

To achieve this singular destination image and position the destination in tourists' minds, destination managers need to communicate (Mak, 2017). Beyond delimiting a competitive strategic positioning on the market, actions conducted during the strategy implementation and, in particular, communication practices are critical for transmitting a consistent image over time (Keller, 2008). In the era of a communication society, destinations need to compete first online. Official communications of destinations have thus become a reflection of the competitive strategy and of everything the place has to offer (LunaNevarez \& Hyman, 2012). After all, users expect to find the most characteristic aspects of a brand projected in the destination's communications (Oliveira, 2013; Torkington, 2012).

\subsection{PROJECTED ATTRACTORS IN COMMUNICATION PRACTICES}

The value of territories and tourism practices in the social context has prompted the need for communication practices, now responsible for representing and expanding the traveling experience promise (de Rosa, Bocci, \& Dryjanska, 2017). Potential tourists interpret communication representations as convincing simulations of the reality and faithful descriptors of a destination. In an online context full of images of the place (e.g. official sources, user-generated content, etc), these representations have such importance that potential tourists perceive them as indications of their future experience; they interpret the representation as reality itself (Hunter, 2016). Thus, talking about destination management necessarily means talking about the projected image through communication practices.

Broadly speaking, the projected image is described as the effort to promote favorable and strategically beneficial images of the destination to position it in the consumer's mind and in the market (Daye, 2010). The projected image comprises the desired characteristics of the offer to compete in a market niche broadcast through communication practices (Mak, 2017). It is related to the reality of the destination's attractors and the way this reality is interpreted by tourists (Crouch, 2011). Thus, destination managers need to work to promote not only the tangible attractors but also the desired perception. Stories 
transmitted repeatedly in a succession of coherent messages strengthen the destination's image perception (Cho \& Sung, 2012; Roberts, 2005).

Consequently, the possibilities online sources offer to the field of tourism have awakened the interest of both practitioners and researchers (Opoku, 2009; Standing et al., 2014). Currently, tourists show complex information-search behaviors combining, necessarily, offline and online sources (Ho, Lin, \& Chen, 2012). Tourists rely on multiple information sources to fulfill their information needs; thus, they are exposed to a number of contributions to the destination image (Kourouthanassis, Mikalef, Pappas, \& Kostagiolas, 2017). In this pool of information sources, Destination Management Organizations' [DMOs] official online platforms are among the most useful for strengthening the destination's image (Molinillo, Liébana-Cabanillas, Anaya-Sánchez, \& Buhalis, 2018). Thus, destination managers need to strategically select official communication channels.

For instance, recent research delved into the role of several official information sources in tourists' information-search behaviors. While some research points to the strong influence of social media in shaping the new trends on information-search behavior (Xiang, Magnini, \& Fesenmaier, 2015), other studies highlight that tools such as official websites exert a stronger influence on destination image perception than social media platforms do (i.e. Instagram, YouTube, Facebook) (Molinillo et al., 2018). Additionally, different from the widespread usage of websites, social media usage remains more prevalent in particular tourists segments, such as millennials (Xiang et al., 2015).

Furthermore, previous studies found a significant influence of official websites on tourists' perceived image of a destination and on their intentions to travel (Kim \& Fesenmaier, 2008; Lepp, Gibson, \& Lane, 2014; Morrison, 2013). In this vein, Luna-Nevarez and Hyman (2012) describe the official website as a destination representative on the Internet, a reflection of everything the destination has to offer. Thus, to compete and differentiate from competitors, destination managers need to project a highly competitive image through their website communications (Morrison, 2013; Opoku, 2009; Vinyals-Mirabent \& Mohammadi, 2018).

Regarding user behavior on the website, even though it is not linear (Morville \& Rosenfeld, 2006), users inspect several pages of the website until it satisfies their informational needs (Radinsky et al., 2013). It is critical then to optimize the hierarchical organization of content to ensure the visibility of those types of content more relevant for the destination's desired positioning. Users should be exposed to information the most allied with strategic interests. Official websites must articulate a coherent and compelling discourse guiding users through the sites' contents (Fernández-Cavia, Rovira, Díaz-Luque, \& Cavaller, 2014; Fernández-Cavia, Vinyals-Mirabent, \& López, 2013; Inversini, Cantoni, \& De Pietro, 2014; Park \& Gretzel, 2007). When done correctly, the official website's discourse is a true reflection of those attractors the destination managers aim to position strategically (Luna-Nevarez \& Hyman, 2012; Oliveira, 2013).

\section{RESEARCH DESIGN}

To identify the main attractors used in destination image representation a two-stage methodological approach based on content analysis is designed. First, previous research 
contributions are explored to delimit a list of categories of attractions. Second, DMOs' official websites of the most popular European urban destinations are analyzed as a reflection of their attractors' promotion strategies. The investigation uses the software NVivo to support the analysis. NVivo 10 is a highly flexible qualitative data analysis software useful for managing, shaping, and examining multimedia content (Bazeley \& Jackson, 2013).

\subsection{CATEGORIZATION OF ATTRACTORS}

At the initial stage, the author defined categories of attractors useful for comparing the different cases. With that goal, the eight studies contained in Table 1 were found to include an explicit list of attractors describing the destinations, and these were thoroughly examined. These studies combined city-centered lists of attractors and broader listings (i.e. regions and nations) with the goal of creating an extensive and complete list of attractors later tested in the analysis. A hundred and eight attractors contained in the previous literature were analyzed and regrouped into broader categories common to the studies to obtain a single operative list of categories. The author followed three criteria to identify the points of overlap among the previous studies. [1] Label diversity: different studies use different names to classify the same attractors. These names were integrated under a single label (e.g. landscape, visual appeal, scenery are all used to refer to landscape and the natural environment). [2] Multiple approaches to the same attributes: some studies highlight the same trait more than once with a different qualitative approach. For this study, only the actual attractor is of use. Thus, these qualitative approaches were dismissed (e.g. cleanliness of accommodation and low-priced accommodation are both considered part of the category accommodation). [3] Generalizable attractors: most of the analyzed studies focus on a single case. Thus, to obtain a generalizable list of categories useful for more than a particular case, only the attractors highlighted by more than two studies were included in the final list of categories.

Table 1. Previous studies highlighting a list of attractors associated with the destinations ${ }^{1}$

\begin{tabular}{l|l|l}
\hline Reference & Attractors & No \\
\hline \hline $\begin{array}{l}\text { Echtner \& Ritchie } \\
\text { (1993) }\end{array}$ & $\begin{array}{l}\text { Tourist sites and activities; National parks and wilderness activities; Historic sites and museums; } \\
\text { Beaches; Fairs, exhibits, festivals; Scenery and natural attractions; Nightlife and entertainment; } \\
\text { Journal of Travel } \\
\text { Research }\end{array}$ & $\begin{array}{l}\text { Shopping facilities; Facilities for information and tours; Sports facilities and activities; Local } \\
\text { infrastructure and transportation; Accommodation and restaurants; Architecture and buildings; } \\
\text { Personal safety; Customs and culture; Hospitality, friendliness, and receptiveness; Atmosphere. }\end{array}$ \\
$\begin{array}{l}\text { Beerli \& Martín } \\
\text { (2004) }\end{array}$ & $\begin{array}{l}\text { Natural resources; General infrastructure; Tourist information; Tourist leisure and recreation; } \\
\text { Annals of Tourism } \\
\text { Research }\end{array}$ & $\begin{array}{l}\text { Culture, history and art; Political and economic factors; Natural environment; Social } \\
\text { environment; Atmosphere of the place. }\end{array}$ \\
$\begin{array}{l}\text { Enright \& Newton } \\
\text { (2005) }\end{array}$ & $\begin{array}{l}\text { Safety; Cuisine; Dedicated tourism attractions; Visual appeal; Well-known landmarks; Nightlife; } \\
\text { Journal of Travel } \\
\text { Research }\end{array}$ & $\begin{array}{l}\text { Different culture; Special events; Interesting architecture; Interesting festivals; Climate; Local way } \\
\text { of life; Notable history; Museums and galleries; Music and performances. }\end{array}$
\end{tabular}

\footnotetext{
${ }^{1}$ Echtner and Ritchie's (1993) study highlights 35 items counting both symbolic and functional attributes. Seventeen of these are closer to the functional dimension.
} 
Prayag (2007)

Tourism

Choi, Lehto \&

Morrison

(2007) Tourism

Management

Tang, Choi, Morrison

\& Lehto

(2009) Journal of

Vacation Marketing

Mazanec \& Wöber

(2010) Book:

SpringerWien

Wong \& Teoh (2015)

Journal of

Destination

Marketing \&

Management
Friendly people; Safety; Good weather; Variety of activities; Service level; Variety of tourist attractions and natural scenery; Culture; Nightlife and entertainment; Transport and infrastructure facilities; Variety of accommodation.

Historic buildings and heritage; Cultural events and facilities (museums, art centers, concerts, etc); Parks and gardens (places for relaxing from city life); Shopping; Tourism facilities and infrastructure (transportation facilities, hotels, convention facilities, etc); Entertainment and gaming; Bird's eye or natural views; Local cuisine and dining; Sports, recreation activities and festivals; People and local residents; Others (maps, flags, and other photographic images).

Description; Entertainment; Transportation; Sightseeing; Food; History; Shopping; Tourism; Accommodation.

City architecture; Culture, art \& entertainment event; Landscape, nature; Weather, climate; Overall quality of accommodation; Comfort \& cleanliness of accommodation; Reachability of the region; Social life; Friendly service staff; Quality of hiking and walking paths; Friendliness of the local population; Quality of food \& beverages; Communication with locals; Low-priced accommodation; Peace and quiet; Public transport within the region; Low-priced package with transport \& accommodation; Low-priced transport; Offering for children; Sports facilities; Bad weather facilities; All-inclusive package; Fairs and exhibitions.

Safety; Cuisine; Dedicated tourism attractions; Visual appeal; Well-known landmarks; Nightlife; Different culture; Special events; Interesting festivals; Local way of life; Interesting architecture; Climate; Notable history; Museums and galleries; Music and performances.

As a result, the common denominator to the studies included 17 relevant categories of attractors to describe the overall destination's attractiveness. After a pilot to test these categories, evidence about other types of content leads the author to include an additional category named 'wellness' and to divide the original 'tourist attractions and activities' into two categories: 'cultural attractions' and 'leisure attractions.' The final list of attractors included 19 categories, described and exemplified, with headlines coded in NVivo within each group, which can be found in Table 2 .

Table 2. Final list of categories of attractors

\begin{tabular}{|c|c|c|}
\hline $\begin{array}{l}\text { Categories of } \\
\text { attractors }\end{array}$ & Short description & Examples (headlines coded in NVivo) \\
\hline Accommodation & $\begin{array}{l}\text { Focused on sleeping places and their characteristics: } \\
\text { hotels, hostels, apartments, etc. }\end{array}$ & 'Family friendly hotels in London' \\
\hline $\begin{array}{l}\text { Architecture \& } \\
\text { heritage }\end{array}$ & $\begin{array}{l}\text { Monuments, archeological sites, singular buildings, } \\
\text { shipwrecks, etc. }\end{array}$ & 'Duomo di Milano-Cathedral' \\
\hline Climate & General climate, temperature, and weather. & 'Amsterdam weather' \\
\hline Cultural attractions & $\begin{array}{l}\text { Stable cultural offering of the place: museums, art } \\
\text { galleries, exhibitions, cultural agendas, etc. }\end{array}$ & 'Contemporary Art in Paris' \\
\hline $\begin{array}{l}\text { Events, fairs \& } \\
\text { festivals }\end{array}$ & $\begin{array}{l}\text { Events standing out from the general agenda. Music } \\
\text { festivals, celebrity concerts, exceptional exhibitions, } \\
\text { etc. }\end{array}$ & $\begin{array}{l}\text { 'The Parade Theatre Festival' in } \\
\text { Amsterdam }\end{array}$ \\
\hline Food \& drink & $\begin{array}{l}\text { Traditional gastronomy, typical food \& beverages, } \\
\text { restaurants, cellars, etc. }\end{array}$ & 'Barcelona on a plate' \\
\hline $\begin{array}{l}\text { Infrastructure \& } \\
\text { transportation }\end{array}$ & $\begin{array}{l}\text { How to get and move around the city: by train, plane, } \\
\text { bus, boat, public transport, etc. }\end{array}$ & 'Getting around town' in Rome \\
\hline $\begin{array}{l}\text { Landscape \& natural } \\
\text { resources }\end{array}$ & $\begin{array}{l}\text { Content about parks \& gardens, landscape, green } \\
\text { areas, riversides, views, etc. }\end{array}$ & 'Public gardens, parks, woods...' in Paris \\
\hline Leisure attractions & $\begin{array}{l}\text { Recreational activities and attractions such as zoos, } \\
\text { swimming pools, casinos, theme parks, etc. }\end{array}$ & $\begin{array}{l}\text { 'Puppet Theatre in El Retiro Park' in } \\
\text { Madrid }\end{array}$ \\
\hline
\end{tabular}




\begin{tabular}{|c|c|c|}
\hline $\begin{array}{l}\text { Local culture \& } \\
\text { history }\end{array}$ & $\begin{array}{l}\text { Content about the history of the city, cultural legacy, } \\
\text { and the place's evolution over time. }\end{array}$ & 'Roman \& Byzantine Istanbul' \\
\hline Local lifestyle & $\begin{array}{l}\text { Character of the population, daily life, locals, } \\
\text { socializing, different neighborhoods lifestyle, etc. }\end{array}$ & 'From the Istanbulities' \\
\hline Nightlife & $\begin{array}{l}\text { Nightclubs, cocktail bars, night walks, and other night } \\
\text { activities. }\end{array}$ & 'Viennese nightlife' \\
\hline $\begin{array}{l}\text { Political \& economic } \\
\text { factors }\end{array}$ & $\begin{array}{l}\text { Information about the government; political stability } \\
\text { of the country, money, currency, money change, etc. }\end{array}$ & $\begin{array}{l}\text { 'What you need to know-currency' in } \\
\text { Prague }\end{array}$ \\
\hline Safety & $\begin{array}{l}\text { Safety of the destination, contacts to safe and orderly } \\
\text { forces, safe ways to travel, etc. }\end{array}$ & 'Emergency \& Help' in Munich \\
\hline Service & $\begin{array}{l}\text { Information about the service staff, personalized } \\
\text { attention, contacts to support services, etc. }\end{array}$ & $\begin{array}{l}\text { 'Vienna's city guides. Here they } \\
\text { introduce themselves.' }\end{array}$ \\
\hline Shopping & $\begin{array}{l}\text { Shopping areas, attractive shops and commercial } \\
\text { areas, souvenirs shopping, etc. }\end{array}$ & 'Zeil shopping promenade' in Frankfurt \\
\hline Sports & $\begin{array}{l}\text { Physical activities, sports activities outdoors, gyms and } \\
\text { pavilions, popular sports activities, etc. }\end{array}$ & 'Sightseeing on the run' in Cienna \\
\hline $\begin{array}{l}\text { Tourism products \& } \\
\text { packages }\end{array}$ & $\begin{array}{l}\text { Activities and packages prepared by the tourism office } \\
\text { and other stakeholders: sightseeing bus, organized } \\
\text { tours, city cards, etc. }\end{array}$ & 'Frankfurt Card' \\
\hline Wellness & $\begin{array}{l}\text { Spas, wellness, ways to get away from the city stress, } \\
\text { thermal facilities, etc. }\end{array}$ & 'Spas and wellness' in Rome \\
\hline
\end{tabular}

\subsection{SAMPLE AND DATA COLLECTION}

The study analyzes the DMOs' official websites of the twelve most popular urban destinations in Europe. The sample is a nonprobability and purposive one (Ruiz Olabuénaga, Aristegui, \& Melgosa, 1998) based on macroeconomic criteria using a preexisting index to evaluate the importance of the destinations: the Global Destination Cities Index [GDC] (Hedrick-Wong \& Choong, 2015). This ranking evaluates the city's popularity among international tourists, providing an accurate estimation of overnight visitors. All European cities among the report's Top 10 Destination Cities in Europe (available from 2011 to 2016 at the date of analysis) were included in the study. The final sample comprises the twelve official websites managed by the official tourism organizations of the following cities: London, Paris, Istanbul, Barcelona, Amsterdam, Milan, Rome, Vienna, Prague, Munich, Madrid, and Frankfurt.

To select the pages to analyze, the researcher adopted a user-navigation criterion. Following previous work proving the validity of the first two levels of the hierarchy to gather significant data about the brand image (Kim \& Lehto, 2012), the home page plus all the pages in the first two levels of the hierarchy of the English version of the site were downloaded. Even though other types of navigation systems exist, such as those based on databases or hypertextual navigation (Morville \& Rosenfeld, 2006), the hierarchical navigation prevailed in all the websites of the sample. Thus, regardless of the superficial layout characteristics, following the global navigation system underlying all the websites of the sample (i.e. the main menu) was useful for determining the corpus (Morville \& Rosenfeld, 2006). Furthermore, only the pages contained within the limits of the official website's URL were considered; the study did not analyze links to external domains. The sample was collected between $15^{\text {th }}$ July and $15^{\text {th }}$ August 2016. Altogether, 779 useful pages were downloaded and analyzed with NVivo 10 software. 
Table 3. Description of the study sample

\begin{tabular}{|c|c|c|c|}
\hline \multicolumn{2}{|l|}{ Websites } & \multirow{2}{*}{$\begin{array}{c}(\mathrm{N}) \\
\begin{array}{c}\text { Pages } \\
\text { downloaded }\end{array} \\
76\end{array}$} & \multirow{2}{*}{$\begin{array}{c}(\mathrm{N}) \\
\begin{array}{c}\text { Content units } \\
\text { coded in NVivo }\end{array} \\
608\end{array}$} \\
\hline Amsterdam & http://www.iamsterdam.com/es/ & & \\
\hline Barcelona & http://www.barcelonaturisme.com & 31 & 313 \\
\hline Frankfurt & http://www.frankfurt-tourismus.de/en/ & 32 & 245 \\
\hline Istanbul & http://howtoistanbul.com/ & 64 & 527 \\
\hline London & http://www.visitlondon.com/ & 92 & 1671 \\
\hline Madrid & http://www.esmadrid.com & 33 & 432 \\
\hline Milan & http://www.tourism.milan.it/ & 52 & 402 \\
\hline Munich & http://www.muenchen.de/int/en & 100 & 812 \\
\hline Paris & http://www.parisinfo.com/ & 124 & 1374 \\
\hline Prague & http://www.prague.eu/en & 74 & 1429 \\
\hline Rome & http://www.turismoroma.it/?lang=en & 46 & 513 \\
\hline Vienna & http://www.wien.info/en & 55 & 1266 \\
\hline \multicolumn{2}{|l|}{ Total: } & 779 & 9592 \\
\hline
\end{tabular}

\subsection{CONTENT ANALYSIS}

In a second stage, the official websites of the sample were analyzed to identify the prevalence of the content dedicated to the different categories of attractions. The prevalence was assessed via the content unit's frequency of appearance. This study views content units as independent propositions representing a single idea (Strijbos, Martens, Prins, \& Jochems, 2006). Thus, coders were instructed to link each content unit to a single attractor category; categories were defined to contain homogenous content units and to be mutually exclusive (Krippendorff, 2013). Only in a few cases were several attractors mixed within a single content unit; these cases were coded as 'overall statements' and excluded from further analysis. Aware of the ongoing discussion about the importance of analyzing manifest and latent content (Bos \& Tarnai, 1999; Krippendorff, 2013; Malterud, 2001), the author considered only the manifest content grouped into blocks of information (i.e. different $<$ div $>$ elements forming the page). Accordingly, the various units of information could comprise a single headline, longer texts, images, or several of these items combined.

Furthermore, to minimize the influence of personal judgment on the coding process, two measures were adopted (Bos \& Tarnai, 1999; Krippendorff, 2013; Neuendorf, 2017). First, NVivo software, version 10, was used to minimize human errors. Second, a coding pilot was conducted by two coders simultaneously. First, a coding book was provided to both coders to unify their coding criteria. Next, a subsample of pages was selected. It included all home pages plus the three first pages from the first level and the first six pages from the second level. One hundred and twelve pages were analyzed by the two coders, $14.4 \%$ of the total sample. The average Kappa coefficient of all analyzed pages indicated a 0.93 agreement between coders. Afterwards, a single coder finished the process of categorization. 


\section{RESULTS AND DISCUSSION}

The process of codification identified 9592 content units related to the attractor categories. The analysis excluded those content units containing overall statements about the brand (e.g. Romantic Paris, unforgettable moments to cherish forever, etc) (Echtner \& Ritchie, 1993). Table 3 contains the number of pages downloaded and the content units coded from each website of the sample. Even though each site was downloaded based on the same criteria (homepage plus two levels deep in the hierarchy), the number of pages in each structural level and the number of content units contained varies by site, which can complicate the analysis (Neuendorf, 2017; Strijbos et al., 2006).

To avoid the possible bias sites with a greater number of content units would exert, all the references were weighted considering their number per website. Hence, in Figure 1 the author summarizes the average percentage of content units dedicated to the different attractors' information and the corresponding standard deviation.

Figure 1. Average scores of the different attractors

\begin{tabular}{|c|c|c|c|c|c|c|}
\hline & Attributes: & $\begin{array}{c}\text { Average } \\
\text { number of } \\
\text { content units }\end{array}$ & $\begin{array}{l}\text { Standard } \\
\text { deviation }\end{array}$ & & & \multirow[b]{2}{*}{$16.90 \%$} \\
\hline [1] & Tourism products \& packages & 0.169 & 0.080 & & & \\
\hline [2] & Cultural attractions \& activities & 0.153 & 0.068 & & & \multirow[t]{18}{*}{$15.28 \%$} \\
\hline [3] & Food \& drink & 0.111 & 0.051 & & \multirow[t]{17}{*}{$11.07 \%$} & \\
\hline [4] & Infrastructure \& transportation & 0.065 & 0.022 & $6.47 \%$ & & \\
\hline [5] & Architecture \& heritage & 0.064 & 0.051 & $6.39 \%$ & & \\
\hline [6] & Landscape \& natural resources & 0.061 & 0.028 & $6.10 \%$ & & \\
\hline [7] & Accommodation & 0.054 & 0.050 & $5.36 \%$ & & \\
\hline [8] & Shopping & 0.053 & 0.036 & $5.33 \%$ & & \\
\hline [9] & Events, fairs \& festivals & 0.047 & 0.018 & $4.67 \%$ & & \\
\hline [10] & Leisure attractions \& activities & 0.033 & 0.020 & \multirow{2}{*}{$\begin{array}{l}3.35 \% \\
3.23 \%\end{array}$} & & \\
\hline [11] & Sports & 0.032 & 0.018 & & & \\
\hline [12] & Local culture \& history & 0.028 & 0.024 & $2.84 \%$ & & \\
\hline [13] & Social life \& locals & 0.028 & 0.027 & $2.76 \%$ & & \\
\hline [14] & Nightlife & 0.015 & 0.012 & $1.53 \%$ & & \\
\hline [15] & Climate & 0.014 & 0.020 & $1.39 \%$ & & \\
\hline [16] & Safety & 0.012 & 0.017 & $1.16 \%$ & & \\
\hline [17] & Political \& economic factors & 0.009 & 0.018 & $0.93 \%$ & & \\
\hline [18] & Service & 0.009 & 0.008 & $0.92 \%$ & & \\
\hline [19] & Wellness & 0.005 & 0.007 & $0.49 \%$ & & \\
\hline
\end{tabular}

\subsection{PREVALENCE OF ATTRACTORS ON THE WEBSITE}

The data in Figure 1 reveal significant differences among the amounts of content dedicated to the different attractors. For instance, the average scores of [1] tourism products and packages, [2] cultural attractions, and [3] food and drink stand out. All 12 cities of the sample show a significant amount of content dedicated to these topics, and the average scores and standard deviations evince the high relevance of these topics in all websites. More than $40 \%$ of the content analyzed is dedicated to these three categories of attractors. These categories represent double the amount of content, or almost double in the case of food and drink, than the fourth-most present topic on the websites: $16.90 \%, 15.28 \%$, and 
$11.07 \%$ versus the $6.47 \%$ achieved by infrastructure and transportation. The prevalence of these attractors across all the cases points to their critical role in competing in the niche of urban destinations.

At the opposite end, [19] wellness, [18] services, [17] political and economic factors, [16] safety, and [15] climate are represented by a very low percentage of content. Most destinations dedicated no content to these attractors, and those who did only devoted very few content units to it. This dearth of data this resulted in very low average scores and high standard deviations, indicating the low significance of these attractors in competing online through official communications. Consequently, while data from these categories could still be valuable for explaining individual cases, they do not appear to be good representatives of the whole group (Ritchey, 2008). These results are interpreted as fortuitous content nonrelevant to the urban destinations segment. Thus, they are excluded from further analysis to ensure a sufficient number of observations relevant to making meaningful conclusions (King, Keohane, \& Verba, 2000).

Between these categories, the results achieved by the remaining 11 types of attractors fluctuate among cases and are less clear to interpret. On the one hand, similar to the three most prevalent attractors, [4] infrastructure and transportation (6.47\%), [6] landscape and natural resources (6.1\%), and [9] events, fairs, and festivals (4.67\%) show a stable presence across the 12 official websites of the sample, as indicated by the low standard deviations: $0.022,0.028$, and 0.018 , respectively. However, these attractors appear to be less prominent in the website's discourse than the three main ones. On the other hand, the roles of architecture and heritage (6.39\%), accommodation (5.36\%), shopping (5.33\%), leisure attractions (3.35\%), sports (3.23\%), local culture and history (2.84\%), local lifestyle (2.76\%), and nightlife (1.53\%) appear to be more unsteady. According to the standard deviations also contained in Figure 1, the destinations show a greater difference among the visibilities given to these types of content on their official websites' discourse. These results might indicate the potential of these topics for contributing more to the differentiation among destinations on the market. To explore this potential, further study using correspondence analysis would be useful to determine their contributions to the overall projected image.

\subsection{DiFFERENTIATION ROLE OF THE ATTRACTORS}

Correspondence analysis is a multivariate statistical technique used to explore relationships among different qualitative variables (Greenacre, 2007; Greenacre \& Torres, 2002; Whitlark \& Smith, 2001). In short, the main contribution of this technique is the reduction of a multidimensional set of data onto low-dimensional axes, ideally two. It transforms correspondence tables into a graphic depiction showing the proximity among different items in this table (Bendixen, 1996; Greenacre, 2007; Whitlark \& Smith, 2001). Furthermore, correspondence analysis has been proven useful in marketing and tourism research to describe competitive contexts and to delimit those variables most influencing the differentiation of the particular brands in context (Tang, Choi, Morrison, \& Lehto, 2009). Table 4 contains descriptive information about the data processed with correspondence analysis; a $\mathrm{p}<0.001$ indicates the high significance of the test. The 11 categories of attractors showing a moderated presence on the official websites (between $6.5 \%$ and $1.5 \%$ ) are tested. 
Table 4. Correspondence analysis data description

\begin{tabular}{|c|c|c|c|c|c|c|c|c|c|}
\hline \multirow[b]{2}{*}{ Dimension } & \multirow{2}{*}{$\begin{array}{l}\text { Singular } \\
\text { value }\end{array}$} & \multirow[b]{2}{*}{ Inertia } & \multirow[b]{2}{*}{$x^{2}$} & \multirow[b]{2}{*}{ Sig. } & \multicolumn{2}{|c|}{ Proportion of inertia } & \multicolumn{3}{|c|}{$\begin{array}{l}\text { Confidence singular value } \\
\qquad \quad \text { Correlation }\end{array}$} \\
\hline & & & & & Accounted for & Cumulative & SD & 2 & 3 \\
\hline 1 & 0.350 & 0.123 & & & 0.336 & 0.336 & 0.013 & 0.135 & 0.041 \\
\hline 2 & 0.295 & 0.087 & & & 0.239 & 0.575 & 0.016 & & 0.086 \\
\hline 3 & 0.240 & 0.058 & & & 0.158 & 0.733 & 0.014 & & \\
\hline 4 & 0.219 & 0.048 & & & 0.131 & 0.864 & & & \\
\hline 5 & 0.151 & 0.023 & & & 0.062 & 0.927 & & & \\
\hline 6 & 0.110 & 0.012 & & & 0.033 & 0.96 & & & \\
\hline 7 & 0.081 & 0.007 & & & 0.018 & 0.978 & & & \\
\hline 8 & 0.065 & 0.004 & & & 0.011 & 0.99 & & & \\
\hline 9 & 0.055 & 0.003 & & & 0.008 & 0.998 & & & \\
\hline 10 & 0.028 & 0.001 & & & 0.002 & 1.000 & & & \\
\hline Total & & 0.364 & 1696.968 & $0.000^{\mathrm{a}}$ & 1.000 & 1.000 & & & \\
\hline
\end{tabular}

This analysis identified ten dimensions explaining the variations across cases; the proportion of inertia indicates the amount of variance explained by each dimension. From the results summarized in Table 4, we can observe the majority of variability across cases can be explained by a small subset of dimensions (Greenacre, 2007; Whitlark \& Smith, 2001). In particular, taking only the first five dimensions covers $92.7 \%$ of all variance found in the data. However, the ideal solution is to reduce dimensionality to two dimensions, given this simplification remains sufficiently significant with only a minor loss of information (Whitlark \& Smith, 2001). In this case, the first two dimensions explain only $57.5 \%$ of the variance, omitting almost half of the available information. Hence, the author added a third dimension to interpret the correspondence analysis. Together, these dimensions explain $33.6 \%, 23.9 \%$ and $15.8 \%$ of the information contained in the data, totaling $73.3 \%$.

Figure 2. Average scores of the different attractors
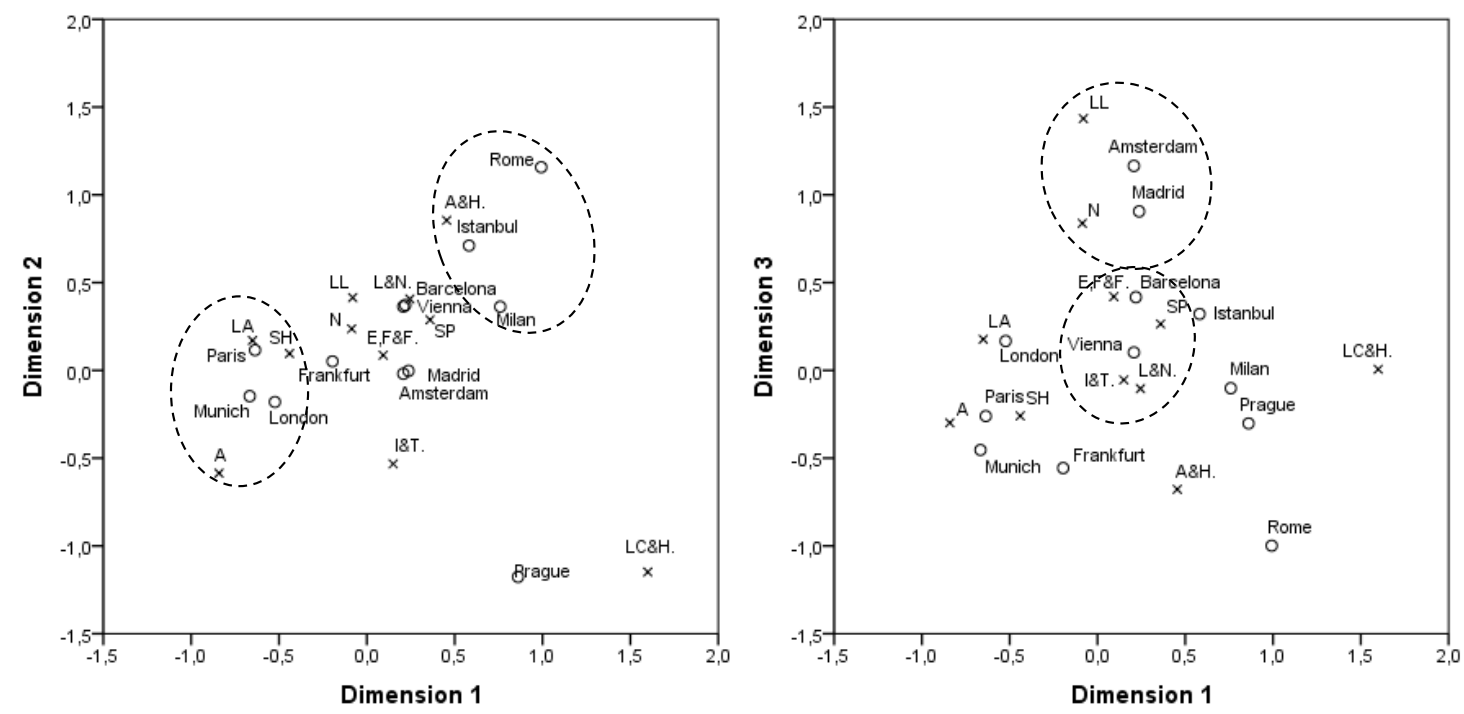

Note: Accommodation [A]; Architecture \& heritage [A\&H]; Events, fairs \& festivals [E,F\&F]; Infrastructure \& transportation [I\&T]; Landscape \& natural resources [L\&N]; Leisure attractions [LA]; Local culture \& history [LC\&H]; Local lifestyle [LL]; Nightlife [N]; Shopping [SH]; and Sports [SP]. 
The information represented in Figure 2 allows the identification of three main tendencies of the attractors' information to distinguish the destinations. Dimension one [D1], explaining the majority of the variance among brands or attractors, is delimited mainly by accommodation, leisure, and shopping on the one hand and by local culture and history together with architecture and heritage on the other one. According to axis D1, Munich, Paris, and London would project similar characteristics stronger in accommodation, leisure, and shopping in contrast with Rome, Prague, Milan, and Istanbul, which proportionally give more relevance to history and architecture and heritage than the remaining destinations of the sample.

While the second dimension [D2] is similarly delimited by local culture on the one hand, together with accommodation and infrastructure and transportation, it is opposed by architecture and heritage on the other. The contribution of axis D2 is to discriminate among destinations clustered at the right end of the D1 axis. Rome and Istanbul differ from Prague due to a higher presence of architecture and heritage content versus the higher emphasis on history by Prague. However, this axis does not appear to separate the remaining destinations.

Finally, projections on the third dimension [D3] reveal relevant information regarding the destinations remaining close to the centroid of the previous two axes (i.e. Frankfurt, Amsterdam, Vienna, Barcelona and Madrid). This axis explains 15.8\% of the differentiation among the destinations; it is mainly driven by differences between information about architecture and heritage on the one hand and local lifestyle and nightlife on the other. According to axis D3, Amsterdam and Madrid project a stronger image on local lifestyle and nightlife, contrasting with the greater emphasis Frankfurt exerts on architecture and heritage. Vienna and Barcelona remain closer to the centroid, indicating a balance between the attractors' information more similar to the average results. Thus, they become more direct competitors to each other. Not surprisingly, attractors related to infrastructure and transportation; landscape and natural resources; and events, fairs, and festivals, remain very little involved in explaining the differences among destinations. This result is consistent with Figure 1, indicating a more stable presence of these attractors across the sample.

Correspondence analysis does not illustrate proportional proximity between the cities and categories of attractors (e.g. Paris being next to shopping does not mean shopping is the most dominant content on the website). The representation is only proportional among different cities or attractors. Thus, the closeness of a city to a specific attractor only indicates a higher presence of this type of content compared to the average scores, which contributes to a higher differentiation.

\section{IMPLICATIONS AND CONCLUSIONS}

The results of the present article contribute to delimiting the roles attractors exert to position a destination on the online arena, either as compulsory components to compete in this specific market, related to competitiveness, or as distinguishing features of particular destinations, associated with a unique destination image. The high presence of certain attractors on all the destinations' websites points to the role of these features as a basic need rather than in differentiating the brand. In contrast, some attractors 
highlighted in the general literature about competitiveness and destination image appear to be irrelevant in competing online, or, at least, in configuring the desired positioning of the destination by its managers. Political and economic matters, the climate, information about services, safety, and wellness appear to be nonrelevant in positioning the destinations in the online context. However, several attractors appear to be key features in differentiating a destination from competitors in the European context.

Altogether, the results point to the clear need of promoting the city's tourism products and packages, cultural attractions, and gastronomy in competing online as a European urban destination. Additionally, infrastructure and transportation, landscape and natural resources, events, and sports also appear to have a more stable presence across communication practices, even though these categories are less prominent in the discourse than the previous ones. These attractors' performances in the discourse leads to a lower inclination to contribute to the destination's differentiation while remaining relevant to competing in the segment market. Instead, information about architecture and heritage, accommodation, shopping, leisure attractions, local culture and history, local lifestyle, and nightlife is shown to have a differentiating role for destinations within the market segment of urban destinations in Europe.

These results highlight the bias some indicators exert when assessing the competitiveness of European urban destinations. For instance, leisure activities (Hassan, 2000) or accommodation (Lee \& King, 2009) have been shown to be less homogeneously relevant to promoting a destination online; therefore, they are worse indicators of competitiveness. Instead, the results support natural and cultural resources (Schwab et al., 2017), special events and infrastructure (Crouch \& Ritchie, 1999), and cuisine (Enright \& Newton, 2005), among others, as relevant indicators for assessing European urban destinations' competitiveness. Thus, this investigation sheds some light on the need to delimit the characteristics of homogeneous markets, such as European urban destinations, as noted in previous literature (Mazanec \& Ring, 2011; Mendola \& Volo, 2017).

In this regard, the investigation extends previous literature by addressing the lack of specific indicators for describing this competitive context (Ayikoru, 2015; Mendola \& Volo, 2017). The resemblances of the official communication of the most popular destinations in Europe show tourism products and packages; cultural attractions; food and drink; infrastructure and transportation; landscape and natural resources, and events, fairs, and festivals to be required attractors in the context of urban tourism. Thus, to compete online in the European context, urban destinations managers might consider including this type of content to strengthen their competitiveness online, with a particular emphasis on the first three categories. These findings are aligned with previous research about the 50 USA states indicating culture, heritage, and nature are the most emphasized topics on their official destination websites (Lee et al., 2006).

As a benchmark study of the European context, these findings also have significant implications for practitioners who can now outline more precisely the characteristics of the competitive context. The analysis revealed three main axes of differentiation among the urban destinations of the continent that can be utilized by smaller destinations to position themselves in the market. The main difference among the destinations is explained by the dichotomy between recreation-related attractors and cultural-oriented 
ones (axis D1). However, axes D2 and D3 represent a significant source of differentiation. Altogether, the axes identified four clusters of destinations: two located at the poles of D1 and two showing a greater balance among the attractors. At the right pole, a greater emphasis on architecture versus more abstract attributes such as history further differentiates among the destinations in that cluster (D2 separates Roma, Istanbul, and Milan from Prague). Similarly, the emphasis on lifestyle activities refines a final separation among the more balanced central clusters of destinations, as explained in D3. These three main factors among the 12 most popular destinations in Europe can explain more than $70 \%$ of the differences among destinations.

\section{STUDY LIMITATIONS}

This study focuses on the official websites of the most popular urban destinations in Europe. While the official website is considered the reflection of the destination's strategy, an analysis of other information sources contributing to create and strengthen the overall image of a destination would be very insightful. For instance, this limitation could miss the influence certain specialized sources (e.g. booking.com) might exert on the destination managers' decisions, because they might rely on these other platforms to inform tourists about specific products (e.g. accommodation). Similarly, the study might miss the influence of other media messages on the overall perception of the destinations' attractors (Wang, Chan, \& Pan, 2015). Additionally, the mother brand, Europe, is already strongly positioned as a cultural territory (Therkelsen \& Gram, 2010), which will certainly contribute to the positioning of European destinations on consumers' minds.

All these unknown contributions should be addressed in further research by analyzing a variety of information sources. A complete understanding of the relevant attractors to compete online would need to expand the analysis to other sources of information. Nevertheless, the current study concludes with meaningful results depicting the characteristics of attractors' active promotions on official websites created by destination managers and provides new insights for understanding attractors' roles on destinations' strategies, contributing to the literature both about competitiveness and brand image.

\section{ACKNOWLEDGMENTS}

This research work has been partially funded by the project "The tourist on the Web: informational habits and destination choice. ITOURIST" (CSO2014-59896-P), of the Ministry of Economy and Competitiveness of the Spanish Government.

\section{REFERENCES}

Andrades-Caldito, L., Sánchez-Rivero, M., \& Pulido-Fernández, J. I. (2013). Differentiating competitiveness through tourism image assessment. Journal of Travel Research, 52(1), 68-81.

Anholt, S. (2004). Branding places and nations. In R. Clifton, J. Simmons, \& S. Ahmad (Eds.), Brands and branding (pp. 213-226). London: Bloomberg Press.

Ayikoru, M. (2015). Destination competitiveness challenges: A Ugandan perspective. Tourism Management, 50, 142-158. 
Baloglu, S., \& McCleary, K. W. (1999). A model of destination image formation. Annals of Tourism Research, 26(4), 868-897.

Bazeley, P., \& Jackson, K. (2013). Qualitative data analysis with NVivo. London: Sage Publications.

Bendixen, M. (1996). A practical guide to the use of correspondence analysis in marketing research. Marketing Research On-Line, 1, 16-38.

Bos, W., \& Tarnai, C. (1999). Content analysis in empirical social research. International Journal of Educational Research, 31(8), 659-671. h

Cho, M.-H., \& Sung, H. H. (2012). Travel destination websites: Cross-cultural effects on perceived information value and performance evaluation. Journal of Travel \& Tourism Marketing, 29(3), 221-241.

Croes, R. (2011). Measuring and explaining competitiveness in the context of small island destinations. Journal of Travel Research, 50(4), 431-442.

Crouch, G. I. (2011). Destination competitiveness: An analysis of determinant attributes. Journal of Travel Research, 50(1), 27-45.

Crouch, G. I., \& Ritchie, J. R. B. (1999). Tourism, competitiveness, and societal prosperity. Journal of Business Research, 44(3), 137-152.

Daye, M. (2010). Challenges and prospects of differentiating destination brands: The case of Dutch Caribean islands. Journal of Travel \& Tourism Marketing, 27(1), 1-13.

de Rosa, A. S., Bocci, E., \& Dryjanska, L. (2017). Social representations of the European capitals and destination e-branding via multi-channel web communication. Journal of Destination Marketing \& Management, Advance online publication.

de San Eugenio Vela, J. (2011). Teoria i mètodes per a marques de territori. Barcelona: Editorial UOC.

Echtner, C. M., \& Ritchie, J. R. B. (1993). The measurement of destination image: An empirical assessment. Journal of Travel Research, 31(4), 3-13.

Enright, M. J., \& Newton, J. (2005). Determinants of tourism destination competitiveness in Asia Pacific: Comprehensiveness and universality. Journal of Travel Research, 43(4), 339-350.

Fernández-Cavia, J., Marchiori, E., Haven-Tang, C., \& Cantoni, L. (2017). Online communication in Spanish destination marketing organizations. Journal of Vacation Marketing, 23(3), 264-273.

Fernández-Cavia, J., Rovira, C., Díaz-Luque, P., \& Cavaller, V. (2014). Web Quality Index (WQI) for official tourist destination websites. Proposal for an assessment system. Tourism Management Perspectives, 9, 5-13.

Fernández-Cavia, J., Vinyals-Mirabent, S., \& López, M. (2013). Calidad de los sitios web turísticos oficiales de las comunidades autónomas españolas. BiD: Textos Universitaris de Biblioteconomia i Documentació, 31.

Greenacre, M. J. (2007). Correspondence analysis in practice (2nd ed.). Boca Raton: Chapman \& Hall/CRC.

Greenacre, M. J., \& Torres, A. (2002). Measuring asymmetries in brand sssociations using correspondence analysis. Barcelona : Universitat Pompeu Fabra.

Hassan, S. S. (2000). Determinants of market competitiveness in an environmentally sustainable tourism industry. Journal of Travel Research, 38(3), 239-245.

Hedrick-Wong, Y., \& Choong, D. (2015). MasterCard Global Destination Cities Index. Retrieved 13.07.16. from: <https://newsroom.mastercard.com/asiapacific/files/2015/06/MasterCard_GDCI-2015.pdf>

Ho, C.-I., Lin, M.-H., \& Chen, H.-M. (2012). Web users' behavioural patterns of tourism information search: From online to offline. Tourism Management, 33(6), 1468-1482.

Hong-bumm, K. (1998). Perceived attractiveness of korean destinations. Annals of Tourism Research, 25(2), 340-361.

Hosany, S., Ekinci, Y., \& Uysal, M. (2006). Destination image and destination personality: An application of branding theories to tourism places. Journal of Business Research, $59(5), 638-642$. 
Hunter, W. C. (2016). The social construction of tourism online destination image: A comparative semiotic analysis of the visual representation of Seoul. Tourism Management, 54, 221-229.

Inversini, A., Cantoni, L., \& De Pietro, M. (2014). Destination online communication: Why less is sometimes more. A study of online communications of English destinations. Journal of Travel \& Tourism Marketing, 31(5), 563-575.

Kapferer, J.-N. (2012). The new strategic brand management. Advanced insights \& strategic thinking (5th ed.). London: Kogan.

Kavaratzis, M., \& Ashworth, G. (2010). Place branding: Where do we stand? In G. Ashworth \& M. Kavaratzis (Eds.), Towards effective place brand management: Branding European cities and regions (pp. 1-14). Cheltenham: Edward Elgar.

Keller, K. L. (1993). Conceptualizing, measuring, and managing customer-based brand equity. The Journal of Marketing, 57, 1-22.

Keller, K. L. (2008). Strategic brand management: Building, measuring, and managing brand equity. New Jersey: Prentice Hall.

Keller, K. L., \& Lehmann, D. R. (2006). Brands and branding: Research findings and future priorities. Marketing Science, 25(6), 740-759.

Kim, H., \& Fesenmaier, D. R. (2008). Persuasive design of destination web sites: An analysis of first impression. Journal of Travel Research, 47(1), 3-13.

Kim, S., \& Lehto, X. Y. (2013). Projected and perceived destination brand personalities: The case of South Korea. Journal of Travel Research, 52(1), 117-130.

King, G., Keohane, R. O., \& Verba, S. (2000). El diseño de la investigación social. La inferencia científica en los estudios cualitativos. Madrid: Alianza Editorial.

Kourouthanassis, P. E., Mikalef, P., Pappas, I. O., \& Kostagiolas, P. (2017). Explaining travellers online information satisfaction: A complexity theory approach on information needs, barriers, sources and personal characteristics. Information \& Management, 54(6), 814-824.

Krippendorff, K. (2013). Content analysis: An introduction to its methodology (3rd ed.). London: Sage Publications.

Lee, C.-F., \& King, B. (2009). A determination of destination competitiveness for Taiwan's hot springs tourism sector using the Delphi technique. Journal of Vacation Marketing, 15(3), 243-257.

Lee, G., Cai, L. A., \& O'Leary, J. T. (2006). WWW.Branding.States.US: An analysis of brandbuilding elements in the US state tourism websites. Tourism Management, 27(5), 815-828.

Lepp, A., Gibson, H., \& Lane, C. (2014). The effect of Uganda's official tourism website on travel motivations and constraints. Journal of Travel \& Tourism Marketing, 31(6), 712-730.

Luna-Nevarez, C., \& Hyman, M. R. (2012). Common practices in destination website design. Journal of Destination Marketing \& Management, 1(1-2), 94-106.

MacKay, K. J., \& Fesenmaier, D. R. (1997). Pictorial element of destination in image formation. Annals of Tourism Research, 24(3), 537-565.

Mak, A. H. N. (2017). Online destination image: Comparing national tourism organisation's and tourists' perspectives. Tourism Management, 60, 280-297.

Malterud, K. (2001). Qualitative research: standards, challenges, and guidelines. The Lancet, 358(9280), 483-488.

Martín-Santana, J. D., Beerli-Palacio, A., \& Nazzareno, P. A. (2017). Antecedents and consequences of destination image gap. Annals of Tourism Research, 62, 13-25.

Mazanec, J. A., \& Ring, A. (2011). Tourism destination competitiveness: Second thoughts on the World Economic Forum reports. Tourism Economics, 17(4), 725-751.

Mazanec, J. A., \& Strasser, H. (2007). Perceptions-based analysis of tourism products and service providers. Journal of Travel Research, 45(4), 387-401.

Mazanec, J. A., Wöber, K., \& Zins, A. H. (2007). Tourism destination competitiveness: From definition to explanation? Journal of Travel Research, 46(1), 86-95. 
Mendola, D., \& Volo, S. (2017). Building composite indicators in tourism studies: Measurements and applications in tourism destination competitiveness. Tourism Management, 59, 541-553.

Molinillo, S., Liébana-Cabanillas, F., Anaya-Sánchez, R., \& Buhalis, D. (2018). DMO online platforms: Image and intention to visit. Tourism Management, 65, 116-130.

Morrison, A. M. (2013). Marketing and managing tourism destinations. New York: Routledge.

Morville, P., \& Rosenfeld, L. (2006). Information architecture for the World Wide Web (3rd ed.). Sebastopol: O’Reilly.

Neuendorf, K. A. (2017). The content analysis guidebook (2nd ed.). Los Angeles: SAGE Publications Ltd.

Nogué, J., \& Albet, A. (2007). Cartografía de los cambios sociales y culturales. In J. Romero (Ed.), Geografía humana: Procesos, riesgos e incertidumbres en un mundo globalizado (pp. 173-219). Barcelona: Ariel.

Oliveira, E. (2013). Digital complexity in destination branding: A preliminary analysis to destination Portugal. Journal of Environmental Management and Tourism, 4(2), 6576.

Opoku, R. (2009). Mapping destination personality in cyberspace: An evaluation of country web sites using correspondence analysis. Journal of Internet Commerce, 8(1-2), 7087.

Park, Y. A., \& Gretzel, U. (2007). Success factors for destination marketing web sites: A qualitative meta-analysis. Journal of Travel Research, 46(1), 46-63.

Pike, S. (2005). Tourism destination branding complexity. Journal of Product \& Brand Management, 14(4), 258-259.

Pike, S. (2012). Destination marketing. An integrated marketing communication approach (2nd ed.). New York: Routledge.

Pike, S., \& Page, S. J. (2014). Destination Marketing Organizations and destination marketing: A narrative analysis of the literature. Tourism Management, 41, 202-227.

Qu, H., Kim, L. H., \& Im, H. H. (2011). A model of destination branding: Integrating the concepts of the branding and destination image. Tourism Management, 32(3), 465476.

Radinsky, K., Svore, K. M., Dumais, S. T., Shokouhi, M., Teevan, J., Bocharov, A., \& Horvitz, E. (2013). Behavioral dynamics on the web: Learning, modeling, and prediction. ACM Transactions on Information Systems, 31(3), 1-37.

Ritchey, F. J. (2008). Estadística para las ciencias sociales (2nd ed.). México, D.F.: McGrawHill.

Ritchie, J. R. B., \& Crouch, G. I. (2003). The competitive destination: A sustainable tourism perspective. Wallingford: CABI Publishing.

Roberts, K. (2005). Lovemarks: The future beyond brands (2nd ed.). New York: PowerHowse Books.

Ruiz Olabuénaga, J. L., Aristegui, I., \& Melgosa, L. (1998). Como elaborar un proyecto de investigación social. Bilbao: Universidad de Deusto.

Sack, R. D. (1992). Place, modernity, and the consumer's world: A relational framework for geographical analysis. Baltimore: John Hopkins University Press.

Schwab, K., Martin, C., Samans, R., Moavenzadeh, J., \& Dreniek-Hanouz, M. (2017). Travel \& tourism competitiveness report 2017. Geneva: World Economic Forum. Retrieved 03.07.18. from: <https://www.weforum.org/reports/the-travel-tourismcompetitiveness-report-2017>

Souiden, N., Ladhari, R., \& Chiadmi, N. E. (2017). Destination personality and destination image. Journal of Hospitality and Tourism Management, 32, 54-70.

Standing, C., Tang-Taye, J.-P., \& Boyer, M. (2014). The impact of the Internet in travel and tourism: A research review 2001-2010. Journal of Travel \& Tourism Marketing, 31(1), 82-113.

Stepchenkova, S., \& Morrison, A. M. (2008). Russia's destination image among American 
pleasure travelers: Revisiting Echtner and Ritchie. Tourism Management, 29(3), 548560.

Strijbos, J.-W., Martens, R. L., Prins, F. J., \& Jochems, W. M. G. (2006). Content analysis: What are they talking about? Computers \& Education, 46(1), 29-48.

Tang, L., Choi, S., Morrison, A. M., \& Lehto, X. Y. (2009). The many faces of Macau: A correspondence analysis of the images communicated by online tourism information sources in English and Chinese. Journal of Vacation Marketing, 15(1), 79-94.

Therkelsen, A., \& Gram, M. (2010). Branding Europe - Between nations, regions and continents. Scandinavian Journal of Hospitality and Tourism, 10(2), 107-128.

Torkington, K. (2012). Place and lifestyle migration: The discursive construction of "Glocal" place-identity. Mobilities, 7(1), 71-92.

Vinyals-Mirabent, S., \& Mohammadi, L. (2018). City brand projected personality: a new measure to assess the consistency of projected personality across messages. Communication \& Society, 31(4), 91-108.

Wang, D., Chan, H. (Rena), \& Pan, S. (2015). The impacts of mass media on organic destination image: A case study of Singapore. Asia Pacific Journal of Tourism Research, 20(8), 860-874.

Whitlark, D. B., \& Smith, S. M. (2001). Using correspondence analysis to map relationships. Marketing Research, 13(3), 22-27.

Wong, P. P. W., \& Teoh, K. (2015). The influence of destination competitiveness on customer-based brand equity. Journal of Destination Marketing \& Management, 4(4), 206-212.

Xiang, Z., Magnini, V. P., \& Fesenmaier, D. R. (2015). Information technology and consumer behavior in travel and tourism: Insights from travel planning using the internet. Journal of Retailing and Consumer Services, 22, 244-249.

Zhang, H., Fu, X., Cai, L. A., \& Lu, L. (2014). Destination image and tourist loyalty: A metaanalysis. Tourism Management, 40, 213-223. 